\title{
Effect of molybdenum treatment on the element uptake of food crops in a long-term field experiment
}

\author{
Anita Puskás-Preszner - Béla Kovács - Dávid Andrási - Zita Kata Burján \\ University of Debrecen, Centre for Agricultural and Applied Economic Sciences; Institute of Food Science, Quality Assurance and \\ Microbiology; Böszörményi Str. 138, Debrecen, Hungary; \\ presznera@gar.unideb.hu
}

Keywords: long-term field experiment, plant, food crops, molybdenum, cadmium

SUMMARY

Molybdenum, as a constituent of several important enzymes, is an essential microelement. It can be found in all kind of food naturally at low levels. However, environmental pollution, from natural or anthropogenic sources, can lead to high levels of the metal in plants.

Our study is based on long-term field experiments at Nagyhörcsök, where different levels of soil contamination conditions are simulated. Plant samples were collected from the experiment station to study the behavior of elements: uptake by and transport within the plants, accumulation in different organs, phytotoxicity and effects on the quantity and quality of the crop.

In this study, we present the effect of molybdenum treatment on the uptake of other elements. Molybdenum is proved to be in an antagonist relationship with copper and sulphur, while molybdenum-phosphorus is a synergist interaction.

However, in most of the plants we studied, increasing molybdenum-treatment enhanced cadmium uptake. We found the most significant cadmium accumulation in the case of pea, spinach and red beet.

\section{INTRODUCTION}

The trace element molybdenum is essential for nearly all organisms and forms the catalytic centre of a large variety of enzymes, such as nitrogenase, nitrate reductase, sulphite oxidase, aldehyde oxidase and xanthine oxidoreductases (Berman, 1980; Reilly, 1991; Pyrzynska, 2007). Operation of these enzymes is based on the Mo(VI) - Mo(V)/Mo(IV) valence change (Kalocsai and Pogány, 2007; Greenwood and Earnshaw, 2004). According to Szabó et al. (1987), molybdenum necessary for plants is slight in comparison to other microelements. Average molybdenum content of plant tissues is $0.3-3.0 \mathrm{mg} \mathrm{kg}^{-1}$; however, usually even considerably higher levels do not cause toxic symptoms (Pais, 1984)

It is proved by several experiments that certain elements are in a synergistic (e.g. phosphorus), while others are in an antagonistic (e.g. copper) relationship with molybdenum. Especially Mo-Cu antagonism has been studied in literature, which reports that a higher than average molybdenum uptake induces copper deficiency, as was observed in the case of animals suffering from molybdenum toxicosis: copper concentration in their body was much lower than that of healthy animals. Nevertheless molybdenum toxicosis was curable by dosing copper (Pais, 1980). Also Suttle (1983) studied molybdenum - copper relationship and established that even 4-6 mg kg ${ }^{-1}$ in fodder blocks copper uptake.

In the case of ruminants, molybdenum - sulphate antagonism can also be observed.

\section{MATERIALS AND METHODS}

Our study is based on a long-term field experiment at Nagyhörcsök, where plant and soil samples were collected from the experimental station. Four levels $(0,90,270,810 \mathrm{~kg} / \mathrm{ha})$ of the selected metal salt (Table 1$)$ were added to plots once at initiation in 1991 and were mixed into the ploughed layer $(0-20 \mathrm{~cm})$. The treatments were arranged in a split-plot design with two replications.

Fertilization was done yearly by $100 \mathrm{~kg} \mathrm{ha}^{-1} \mathrm{~N}, \mathrm{P}_{2} \mathrm{O}_{5}$ and $\mathrm{K}_{2} \mathrm{O}$ active agents in the form of ammonium nitrate, superphosphate and potash fertilizers. 
Elements and doses applied in 1991, Nagyhörcsök

\begin{tabular}{|c|c|c|c|c|c|}
\hline \multirow[t]{2}{*}{ Element } & \multicolumn{4}{|c|}{$\begin{array}{l}\text { Dose in spring of 1991, } \\
\qquad \mathrm{kg} \mathrm{ha}^{-1}\end{array}$} & \multirow[t]{2}{*}{ Chemicals applied } \\
\hline & 1 & 2 & 3 & 4 & \\
\hline $\mathrm{Al}$ & - & 90 & 270 & 810 & $\mathrm{AlCl}_{3}$ \\
\hline As & 30 & 90 & 270 & 810 & $\mathrm{As}_{2} \mathrm{O}_{3} / \mathrm{NaAsO}_{2}$ \\
\hline $\mathrm{Ba}$ & - & 90 & 270 & 810 & $\mathrm{BaCl}_{2} \cdot 2 \mathrm{H}_{2} \mathrm{O}$ \\
\hline $\mathrm{Cd}$ & 30 & 90 & 270 & 810 & $\mathrm{CdSO}_{4} \cdot 8 / 3 \mathrm{H}_{2} \mathrm{O}$ \\
\hline $\mathrm{Cr}$ & - & 90 & 270 & 810 & $\mathrm{~K}_{2} \mathrm{CrO}_{4}$ \\
\hline $\mathrm{Cu}$ & - & 90 & 270 & 810 & $\mathrm{CuSO}_{4} \cdot 5 \mathrm{H}_{2} \mathrm{O}$ \\
\hline $\mathrm{Hg}$ & 30 & 90 & 270 & 810 & $\mathrm{HgCl}_{2}$ \\
\hline Mo & - & 90 & 270 & 810 & $\left(\mathrm{NH}_{4}\right)_{6} \mathrm{Mo}_{7} \mathrm{O}_{24} \cdot 4 \mathrm{H}_{2} \mathrm{O}$ \\
\hline $\mathrm{Ni}$ & - & 90 & 270 & 810 & $\mathrm{NiSO}_{4} \cdot 7 \mathrm{H}_{2} \mathrm{O}$ \\
\hline $\mathrm{Pb}$ & - & 90 & 270 & 810 & $\mathrm{~Pb}\left(\mathrm{NO}_{3}\right)_{2}$ \\
\hline $\mathrm{Se}$ & 30 & 90 & 270 & 810 & $\mathrm{Na}_{2} \mathrm{SeO}_{3}$ \\
\hline $\mathrm{Sr}$ & - & 90 & 270 & 810 & $\mathrm{SrSO}_{4}$ \\
\hline $\mathrm{Zn}$ & - & 90 & 270 & 810 & $\mathrm{ZnSO}_{4} \cdot 7 \mathrm{H}_{2} \mathrm{O}$ \\
\hline
\end{tabular}

Source: Kádár I. (1995) - Pollution of the soil-plant animal food chain by chemical elements in Hungary. Hungarian Academy of Sciences, Research Institute for Soil and Agricultural Chemistry, Soil and Plant Analysis Council. p. 175.

\section{Extraction and determination}

During sampling, 20-40 plants per plot were collected, collecting root, shoot, leaf and grain separately. In our study, we analyzed samples of maize (1991), carrot (1992), potato (1993), pea (1994), red beet (1995), spinach (1996), sunflower (1998), garden sorrel (1999) and poppy seed (2000).

To make samples suitable for determination, soil and plant samples alike were dried, ground and subjected to atmospheric wet digestion with nitric acid and hydrogen peroxide (Kovács et al., 1996). Total concentration of elements was determined by inductively coupled plasma optical emission spectroscopy (ICP-OES) (Perkin Elmer OPTIMA 3300 DV) and inductively coupled plasma mass spectrometry (ICP-MS) (Thermo Elemental $\mathrm{X} 7$ ). After that we investigated the effect of molybdenum treatment on the element uptake by One-Way ANOVA using SPSS14.0.

\section{RESULTS AND DISCUSSION}

Connection between increasing molybdenum dose and molybdenum content of plants is close $\left(\mathrm{r}^{2}>0.970\right)$ but this report does not include such data.

The goal of the present experiments was to measure the effect of molybdenum treatment on the uptake of other elements; therefore, a statistical analysis was made (One-Way ANOVA), the results of which are shown in Table 2, where we listed the analyzed plant parts and the elements that significantly differ from the control sample regarding concentration. Also, tendency of change (+/-) is indicated.

(Although at the first level of molybdenum treatment, $0 \mathrm{~kg} \mathrm{ha}^{-1}$ molybdenum was applied separate control sample was used during analysis, because on the basis of preliminary soil examinations, we suppose that carrying over of soil from neighboring plots was possible to a certain extent.)

Effect of molybdenum treatment on the element content of studied plant parts

$$
(* p<0.05 * * p<0.01 * * * p<0.001)
$$

\begin{tabular}{ll}
\hline \multicolumn{1}{c}{ Plant part } & \multicolumn{1}{c}{$\begin{array}{c}\text { Element significantly differing } \\
\text { from control }\end{array}$} \\
\hline Maize grain & $(+) \mathrm{Cd} * * *(+) \mathrm{Ca}$ \\
Maize leaf & $(+) \mathrm{Cd}^{* *}$ \\
Carrot & $(+) \mathrm{Cd}^{*}(-) \mathrm{Cr}^{* * *}$ \\
Potato & $(+) \mathrm{B}^{*}$ \\
Pea seed & $(+) \mathrm{Cd} * *(+) \mathrm{Co} * * *$ \\
Pea straw & $(+) \mathrm{Cd}^{* * *}$ \\
Red beet & $(+) \mathrm{Cd}^{*}$ \\
Spinach & $(+) \mathrm{Cd}^{*}(-) \mathrm{B}^{*}(+) \mathrm{Pb}^{*}$ \\
Sunflower & $(-) \mathrm{Sr}^{*}(-) \mathrm{Cr} *$ \\
Garden sorrel & $(+) \mathrm{Cd}^{*}(+) \mathrm{Mn}^{* *}$ \\
Poppy-head & $(-) \mathrm{Al}^{*}(-) \mathrm{Co}^{*}(-) \mathrm{Fe}^{*}(-) \mathrm{Mn}^{* *}$ \\
Poppy-seed & $(-) \mathrm{Co}^{*}(+) \mathrm{S}^{*}$ \\
\hline
\end{tabular}


We would like to emphasize that cadmium $(\mathrm{Cd})$ shows significantly higher concentrations than in the control sample in the case of eight plant parts from the studied twelve; therefore, we focused on this phenomenon below. Hereafter, change of cadmium uptake of some food crops is presented.

Increasing molybdenum dose enhanced cadmium uptake in maize, similarly to the other five plants (Table 3). However, there is considerable difference between grain and leaf regarding cadmium content, since we experienced higher cadmium concentration with an order of magnitude in leaf than in grain.

Studying cadmium content of pea, we observed a similar relation. See: straw ratio (Table 4).

Effect of molybdenum treatment on cadmium content of maize leaf and grain

Table 3

$(<L O D$ - lower than limit of detection)

\begin{tabular}{cccccccc}
\hline $\begin{array}{c}\text { Mo dose } \\
\left(\mathrm{kg} \mathrm{ha}^{-1}\right)\end{array}$ & \multicolumn{3}{c}{ Maize leaf } & \multicolumn{3}{c}{ Maize grain } \\
\hline control & 0.017 & \pm & 0.004 & 0.003 & \pm & 0.001 \\
0 & 0.090 & \pm & 0.092 & $<$ LOD & \pm & - \\
90 & 0.587 & \pm & 0.000 & 0.014 & \pm & 0.002 \\
270 & 0.996 & \pm & 0.097 & 0.027 & \pm & 0.001 \\
810 & 1.435 & \pm & 0.216 & 0.054 & \pm & 0.009 \\
\hline
\end{tabular}

Effect of molybdenum treatment on cadmium content of pea straw and seed

Table 4

\begin{tabular}{cccccccc}
\hline $\begin{array}{c}\text { Mo dose } \\
\left(\mathrm{kg} \mathrm{ha}^{-1}\right)\end{array}$ & \multicolumn{2}{c}{ Pea straw } & \multicolumn{3}{c}{ Pea seed } \\
\hline control & 0.078 & \pm & 0.028 & 0.089 & \pm & 0.020 \\
0 & 1.899 & \pm & 0.962 & 0.295 & \pm & 0.074 \\
90 & 3.434 & \pm & 0.584 & 0.320 & \pm & 0.005 \\
270 & 6.397 & \pm & 0.055 & 0.404 & \pm & 0.051 \\
810 & 7.115 & \pm & 1.093 & 0.427 & \pm & 0.083 \\
\hline
\end{tabular}

Comparing vegetative and generative organs of the two plants in pairs (maize leaf - pea straw, maize grain - pea seed), a difference of an order of magnitude can be found again.

Lower cadmium content of grains and seeds is due to the fact that generative organs of plants are genetically protected from possible harmful effects (e.g. toxic element accumulation) while difference between maize and pea can be explained by taxonomic reasons. Element uptake mechanism of mono- and dicotyledons happen in different ways.

The rest food crops accumulate cadmium at the same magnitude $\left(0.1-1.0 \mathrm{mg} \mathrm{kg}^{-1}\right)$, but red beet and spinach are striking (Figure 1, 2).

Figure 1. Cadmium content of red beet depending on molybdenum treatment (0 - control, $\left.1-0 \mathrm{~kg} \mathrm{ha} a^{-1}, 2-90 \mathrm{~kg} \mathrm{ha}^{-1}, 3-270 \mathrm{~kg} \mathrm{ha}^{-1}, 4-810 \mathrm{~kg} \mathrm{ha}^{-1}\right)$

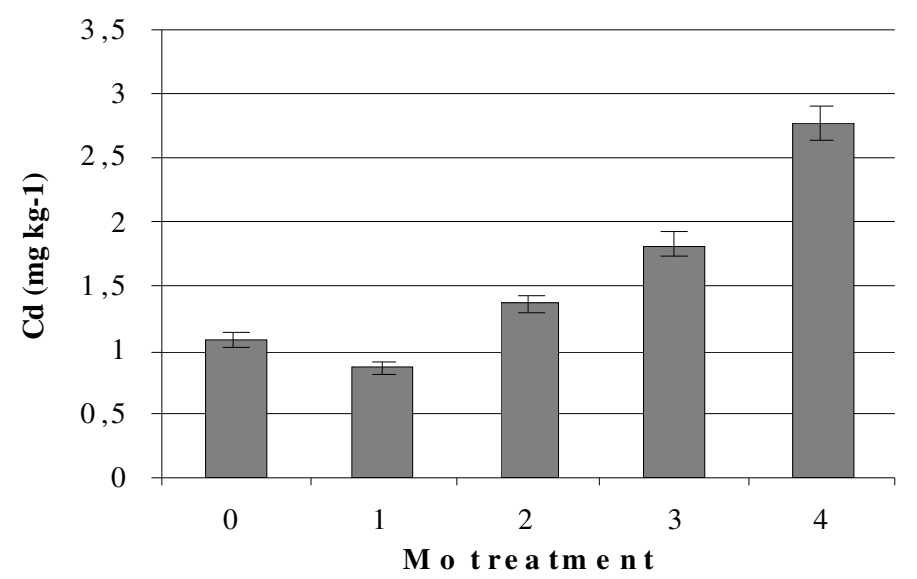


Figure 2: Cadmium content of spinach depending on molybdenum treatment $\left(0\right.$ - control, $\left.1-0 \mathrm{~kg} \mathrm{ha}^{-1}, 2-90 \mathrm{~kg} \mathrm{ha}^{-1}, 3-270 \mathrm{~kg} \mathrm{ha}^{-1}, 4-810 \mathrm{~kg} \mathrm{ha}^{-1}\right)$

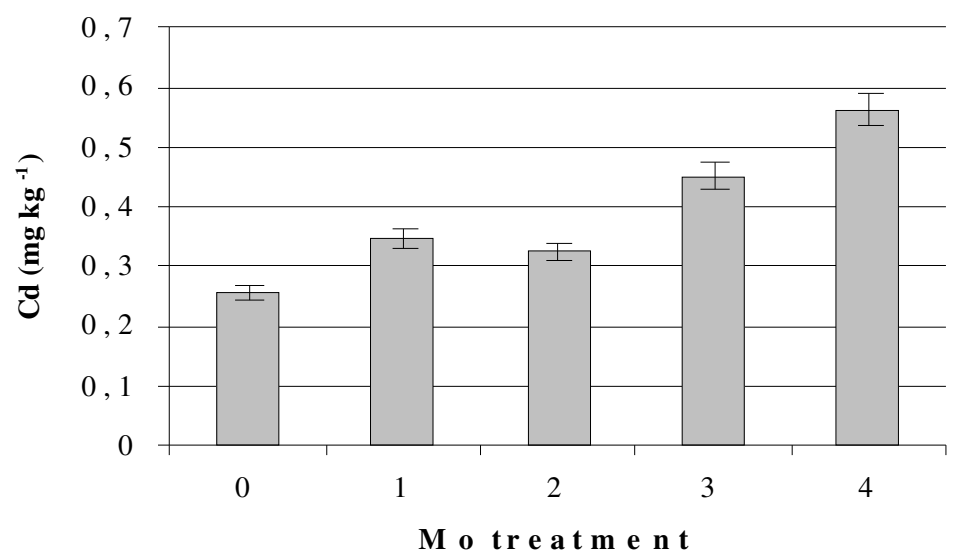

Results of red beet and spinach do not cause any surprise, since other scientists had reported about their cadmium accumulating capability previously (Kádár et al. $2001 \mathrm{a}$, b). However, it makes us think that the plants (papilionaceous, leafy vegetables) requiring more molybdenum took up cadmium in greater quantities.

\section{CONCLUSIONS}

Further investigation is needed to explain increased cadmium uptake of crops from molybdenum-treated plots, but some possible explanations emerge.

The first thought is that molybdenum treated-plots and cadmium-treated plots are bordering and molybdenumtreated plots were polluted by carrying over of soil containing extra cadmium. This possibility can be excluded, since there are six other treatments in replication I and three in replication II between molybdenum and cadmium treatment.

Cadmium content of fertilizers, especially phosphoric fertilizers, can be a significant source of cadmium. Fertilization by these is done yearly applying the same amount on each plot. Due to equal quantities, it is not possible that phosphoric fertilizers induce cadmium uptake increases with molybdenum dose.

It can occur that molybdenum applied in the form of $\left(\mathrm{NH}_{4}\right)_{6} \mathrm{Mo}_{7} \mathrm{O}_{24} \cdot 4 \mathrm{H}_{2} \mathrm{O}$ caused alteration of $\mathrm{pH}$ in soil affecting cadmium uptake positively. If so, molybdenum uptake should have been reduced, since the behaviors of cadmium and molybdenum are the opposite at the same level of $\mathrm{pH}$. However, increasing molybdenum doses may compensate by moderating the molybdenum uptake induced by reduction of $\mathrm{pH}$. In any case, we cannot forget about the role of $\mathrm{pH}$; further investigation has to be done to describe its influence more precisely.

Another possible explanation in connection with instrumental analysis also emerged, whereby ${ }^{94} \mathrm{Mo}^{16} \mathrm{O}^{+}$or ${ }^{95} \mathrm{Mo}^{16} \mathrm{O}^{+}$dimers may form from molybdenum isotopes in the inductively coupled plasma and their mass number is equal to that of ${ }^{110} \mathrm{Cd}$ and ${ }^{111} \mathrm{Cd}$ serving the same $\mathrm{m} / \mathrm{z}$ sign in the detector. Nevertheless, this phenomenon can be avoided by applying CCT (collision cell technology), as was used during our analysis.

The possibility of some kind of interaction between molybdenum and cadmium can be mentioned, but we have not found any references to it in literature and the results of only one experiment are not enough for scientific proof.

\section{REFERENCES}

Berman E. (1980): Toxic metals and their analysis. Heyden \& Son Ltd. 161-166.

Kalocsai R.-Pogány É. (2007): A molibdén jelentősége, előfordulása a talajban, felvétele. MezőHír, XI. 62.

Kádár I. (1995): A talaj-növény-állat tápláléklánc szennyeződése kémiai elemekkel Magyarországon. MTA Talajtani és Agrokémiai Kutató Intézete.

Kádár I.-Koncz J.-Radics L. (2001a): Mikroelem-terhelés hatása céklára karbonátos csernozjom talajon. Agrokémia és talajtan. 50 (3-4). 315-334.

Kádár I.-D. Hussein-Radics L. (2001b): Mikroelem-terhelés hatása spenótra karbonátos csernozjom talajon. Agrokémia és talajtan. 50 (3-4). 334-352.

Kovács B.-Győri Z.-Prokisch J.-Loch J.-Dániel P. (1996): A study of plant sample preparation and inductively coupled plasma atomic emission spectrometry parameters. Communication in Soil Science and Plant Analysis. 27. 5-8. 1177-1198.

Szabó S. A.-Régiusné M. Á.-Győri D.-Szentmihályi S. (1987): Mikroelemek a mezőgazdaságban I. (Esszenciális mikroelemek). Mezőgazdasági Kiadó.133-137, 153.

Pais I. (1980): A mikrotápanyagok szerepe a mezőgazdaságban. Mezőgazda Kiadó, Budapest, 70-71.

Pais I. (1984): A mikroelemek jelentősége a mezőgazdasági termelésben, kutatásuk helyzete a világban. Kertészeti Egyetem kiadványa, 45. 
Pyrzynska K. (2007): Determination of molybdenum in environmental samples. Analytica Chimica Acta. 590. 40-48.

Reilly C. (1991): Metal contamination of food. Elsevier Science Publisher Ltd. 225-229.

Suttle N. F. (1983): J. Agric. Sci. Camb. 100, 651-656.

Széles É.-Kovács B.-Prokisch J.-Győri Z. (2005): Ütközési cella (CCT) alkalmazása az ICP-MS technikában. Agrártudományi közlemények. 2005/16.120-125. 